\title{
The happiness of small-scale dairy farmers: A case at Malang Regency of East Java, Indonesia
}

\author{
S. Sutawi ${ }^{1 *}$, I. Prihartini ${ }^{1}$, K. Khotimah ${ }^{1}$, D. Iswatiningsih ${ }^{2}$, and F. Kusumastuti ${ }^{3}$ \\ ${ }^{1}$ Faculty of Agriculture and Animal Science, University of Muhammadiyah Malang \\ ${ }^{2}$ Faculty of Teacher Training and Education, University of Muhammadiyah Malang \\ ${ }^{3}$ Faculty of Social and Politic, University of Muhammadiyah Malang \\ Jl. Raya Tlogomas 246, Malang 65144, East Java, Indonesia \\ *Corresponding E-mail: sutawi@umm.ac.id
}

Received Februari 27, 2021; Accepted October 06, 2021

\begin{abstract}
This study was conducted to assess the happiness of small-scale dairy cattle farmers based on subjective well-being conditions. The research was conducted in July-October 2020 using a survey method in the Malang Regency of East Java Province. Analysis units were 145 small-scale dairy cattle farmer households purposively selected with less than 30 heads of dairy cattle ownership and have managed their livestock farming for more than five years. Data collection was conducted through interviews about three dimensions of happiness including life satisfaction, affection, and the meaning of life. The three dimensions were divided into 19 indicators to calculate the Happiness Index. The ten Life Satisfaction indicators produced a Life Satisfaction Index of 7.43 (Happy), consisting of a Personal Life Satisfaction Index of 7.26 (Happy) and a Social Life Satisfaction Index of 7.85 (Happy). The three Affection indicators produced the Affection Index of 7.29 (Happy). The six Meaning of Life indicators produced the Meaning of Life Index of 7.44 (Happy). The Happiness Index of small-scale dairy cattle farmers in East Java was 7.43 and classified as "Happy".
\end{abstract}

Keywords: Affection, Dairy farmers, Happiness index, Life satisfaction, Meaning of life

\section{INTRODUCTION}

Dairy production in Indonesia was dominated by small-scale farmers $80 \%$, medium-scale $17 \%$, and large-scale 3\% (Mandaka and $\mathrm{Hu}-$ tagaol, 2005). Small-scale farmers were characterized by keeping 1-5 heads, limited land, semipermanent cowshed, traditional management, family labor, limited capital (Firman et al., 2019). Small-scale dairy farming income was around IDR 526,230/AU/month (Utami and Seruni, 2014). Small-scale dairy farmers were usually ranged in low-income stratum and were even classified as poor. Raising dairy cows has not provided an adequate standard of living for the family of farmers.

Human welfare was not only determined by economic indicators, but also by social indicators. Welfare no longer describes a condition of material prosperity but leads to the concept of happiness. Happiness has a meaning and scope that was not only limited to conditions of material prosperity but also in conditions of a good life and meaningful life conditions. Happiness de- 
scribes the level of subjective well-being includes three dimensions, namely life satisfaction, affection, and the meaning of life (Dodge et al., 2012).

Research on the welfare of dairy farmers generally examines social and economic aspects, while psychological aspects were still scarce. This study was conducted to assess the happiness of small-scale dairy cattle farmers in rural East Java based on the subjective well-being conditions that include the dimensions of life satisfaction, affect, and meaning of life. This study adopted a BPS (Statistics Indonesia) survey on population happiness, which was applied to dairy cattle farmers.

\section{MATERIALS AND METHODS}

\section{Sampling and Scoring Methods}

The research was conducted in July-October 2020 using a survey method in the Malang Regency of East Java Province. The respondents were 145 small-scale dairy cattle farmer households purposively selected with less than 30 heads of dairy cattle ownership and have managed their livestock farming for more than five years. The design of this research was a quantitative research technique of scoring (rating scale) to questions related to life satisfaction, affect, and meaning of life, which represented the ladder of life scale on the scale of 0 to 10 . Score 0 showed the answers of farmers about their most dissatisfaction, while score 10 represented the condition of farmers about the most satisfaction. The satisfaction level of farmers was divided into five categories: (1) 0.00-2.00, "Completely Dissatisfied"; (2) 2.014.00, "Dissatisfied"; (3) 4.01-6.00, "Moderately Satisfied"; (4) 6.01-8.00, "Satisfied"; and (5) 8.01 -10.00 , "Completely Satisfied".

\section{Happiness Index Measurement}

The Happiness Index were the composite index composed of three dimensions, two subdimensions, and 19 indicators guided by BPS Survey of Happiness Measurement 2017 (Table 1). The formula used in calculating the dimensions of the components of happiness was as follows (BPS, 2017):

$$
\mathrm{LSI}=\{(\mathrm{w} 4 * \mathrm{PLSI})+(\mathrm{w} 5 * \mathrm{SLSI})\} /(\mathrm{w} 4+\mathrm{w} 5)
$$

PLSI $=\sum(w i * x i) / \sum w i$

SLSI $=\sum(w i * x i) / \sum w i$

$\mathrm{AI}=\sum(\mathrm{wi} * \mathrm{xi}) / \sum \mathrm{wi}$

MLI $=\sum\left(w i^{*} x i\right) / \sum w i$

Afterward, the Happiness Index was calculated by this formula:

$\mathrm{HI}=\{(\mathrm{w} 1 * \mathrm{LSI})+(\mathrm{w} 2 * \mathrm{AI})+(\mathrm{w} 3 * \mathrm{MLI})\} /$

$(\mathrm{w} 1+\mathrm{w} 2+\mathrm{w} 3)$

Where LSI is Life Satisfaction Index; PLSI is Personal Life Satisfaction Index; SLSI is Social Life Satisfaction Index; AI is Affection Index; MLI is Meaning of Life Index; HI is Happiness Index; $x i$ is a score of $i$ indicator; $w i$ is the weight of $i$ indicator, where $i=1, \ldots, 5$ are for Personal Life Satisfaction indicators, $i=6, \ldots, 10$ are for Social Life Satisfaction indicators, $i=$ $11,12,13$ is for Affection indicators, $i=14, \ldots, 19$ are for Meaning of Life indicators; and $w 1, w 2$, $w 3, w 4, w 5$ are the of Life Satisfaction Dimension, Affection Dimension, Meaning of Life Dimension, Personal Life Satisfaction Subdimension, and Social Life Satisfaction Dimension, respectively. The happiness level of farmers as classified into five categories: (1) 0.00 2.00, "Completely Unhappy"; (2) 2.01-4.00, "Unhappy"; (3) 4.01-6.00, "Moderately Happy"; (4) 6.01-8.00, "Happy"; and (5) 8.01-10.00, "Completely Happy".

\section{RESULTS AND DISCUSSION}

\section{Happiness Index}

The scores of 19 indicators compiling the Happiness Index of small-scale dairy farmers were presented in Figure 1. The ten Life Satisfaction indicators produced a Life Satisfaction Index of 7.43 (Happy), consisting of a Personal Life Satisfaction Index of 7.26 (Happy) and a Social Life Satisfaction Index of 7.85 (Happy). The three Affection indicators produced the Affection Index of 7.29 (Happy). The six Meaning of Life indicators produced the Meaning of Life Index of 7.44 (Happy). The Happiness Index of small-scale dairy cattle farmers in East Java Province was 7.43 and classified as "Happy".

\section{Life Satisfaction Dimension}


Table 1. Determination of dimensions, sub-dimensions, indicators, and the weights

\begin{tabular}{|c|c|c|c|c|c|}
\hline \multirow[b]{2}{*}{ Dimensions } & \multirow[b]{2}{*}{ Sub-dimension } & \multirow[b]{2}{*}{ Indicators } & \multirow{2}{*}{$\begin{array}{l}\text { The Weights } \\
\text { (wi) }\end{array}$} & \multicolumn{2}{|c|}{ Indicators Scores (xi) } \\
\hline & & & & $1-2-3-4-5$ & $6-7-8-9-10$ \\
\hline \multirow{11}{*}{$\begin{array}{l}\text { Life } \\
\text { Satisfaction } \\
\text { (w1=34.80) }\end{array}$} & \multirow{5}{*}{$\begin{array}{l}\text { Personal Life } \\
\text { Satisfaction } \\
(w 4=50.00)\end{array}$} & 1. Education and Skills & 18.34 & & \\
\hline & & 2. Main Jobs & 2167 & & \\
\hline & & 3. Household Income & 288 & & \\
\hline & & 4. Health & $\begin{array}{l}22.81 \\
1704\end{array}$ & & \\
\hline & & 5. Housing & 20.14 & & \\
\hline & \multirow{6}{*}{$\begin{array}{l}\text { Social Life } \\
\text { Satisfaction } \\
\text { (w5=50.00) }\end{array}$} & 6. Family Harmony & 104 & & \\
\hline & & & 19.41 & & \\
\hline & & 7. Work and Life Balance & 18.93 & & \\
\hline & & 8. Social Connectedness & 22.13 & & \\
\hline & & 9. Environmental Condition & 20.64 & & \\
\hline & & 10. Security & 18.89 & & \\
\hline \multirow{3}{*}{$\begin{array}{l}\text { Affection } \\
(\mathrm{w} 2=31.18)\end{array}$} & & 11. Positive Emotion & 25.86 & & \\
\hline & & 12. Negative Emotion & 36.80 & & \\
\hline & & 13. Depressed & 37.34 & & \\
\hline \multirow{6}{*}{$\begin{array}{l}\text { Meaning of Life } \\
(\mathrm{w} 3=34.02)\end{array}$} & & 14. Autonomy & 16.56 & & \\
\hline & & 15. Environmental Mastery & 18.44 & & \\
\hline & & 16. Personal Growth & 15.27 & & \\
\hline & & 17. Positive Relation with Others & 15.48 & & \\
\hline & & 18. Purpose in Life & 17.48 & & \\
\hline & & 19. Self-Acceptance & 16.78 & & \\
\hline
\end{tabular}

Source: BPS (2017)

Education and Skills. Farmers' satisfaction with the Education and Skills indicators was 6.52 (Satisfied). As many as $66(66.52 \%)$ farmers had an elementary school, and 50 (34.48\%) farmers in junior high schools, the remaining 25 $(17.24 \%)$ farmers in senior high schools, and 4 $(2.76 \%)$ farmers in colleges/universities. The higher the level of education, the more reluctant farmers were to do field technical work (Sharma, 2016). Farmers gain additional knowledge and skills in raising dairy cows from counseling by the Livestock Service, Technical Service of dairy companies, and universities. Agricultural advisors play a significant role in the transfer of knowledge and good farming practices. The good extension has succeeded in improving the socio-economic well-being (happiness) of the farmers and farming community in general (Maoba, 2016).

Main Jobs. Farmers' satisfaction with the Main Jobs indicator was 7.36 (Satisfied). Dairy farming was the main job of 124 (85.52\%) farm- ers' families. Milk sales account for more than $90 \%$ of the household income (Atmakusuma et al., 2019). Dairy farmers were dominated by old farmers over 40 years old. The change in economic structure from agriculture to industry and services encourages rural youth to work in industrial and service sectors in cities that offer greater and more established wages than raising dairy cows. Young people were not motivated to manage dairy farms because the profits were low, take up a lot of time, and require considerable investment to grow the business (Sharma, 2016).

Household Income. Farmers' satisfaction with Household Income indicator was 7.27 (Satisfied). Farmers keep 8-10 lactation cows with milk production of 10-15 liters/AU/day. Farmers earn IDR 556,650/AU/month, so the total income was IDR 4,453,200-5,566,500/ month. The income of dairy farmers was slightly higher than Indonesia's poverty line standard in 2020 of IDR 454,652/capita/month. Farmers' income varies depending on the number of cows, 
milk production, milk quality, and milk prices. Household income has a positive effect on happiness. The higher the income the higher the happiness level (Yakubu and Aidoo, 2015).

Health. Farmers' satisfaction with the Health indicator was 7.77 (Satisfied). The degree of human health can be determined by education, employment, living environment, and public policy (Islam, 2019). Farmers have managed the sanitation of the cowshed well so that it does not experience health complaints while working in the cowshed (Zuroida and Azizah, 2018). The number of health facilities has a positive and significant effect on the welfare of the community. Good health, on the one hand, will increase happiness, on the other hand, it can happen that happy people will be in higher health (Rahayu, 2016).

Housing. Farmers' satisfaction with Housing was 7.73 (Satisfied). Dairy farmers live in their own houses $(97.06 \%)$, covering $50-100 \mathrm{~m}^{2}$ $(53.28 \%)$, ceramic floors $(56.61 \%)$, roof tiles $(87.02 \%)$, walled walls $(79.85 \%)$, and electric light (99.10\%). An increase in living space has a positive linear effect on life satisfaction and mental health (Foye, 2016). Farmers' houses were generally too close to the cowshed due to land limitations. The animal houses nearby human dwelling provided good management and easy transport of milk (Himani et al., 2018).

Family Harmony. Farmers' satisfaction with the Family Harmony indicator was 8.06 (Completely Satisfied). A harmonious family was contributed by four components: communication, mutual respect, lack of conflict, and having time for family (Lam et al., 2012). Harmony of family life was very important because the family was the reason and motivation to live the best life possible. Family harmony ought to be kept up so that the family can perform their obligations and capacities properly and be balanced (Sari and Puspitawati, 2017).

Work and Life Balance. Farmers' satisfaction with Work-Life Balance was 7.56 (Satisfied). The dairy farmer's family allocated about 1.7-3.83 hours/AU to manage the dairy

1. Education and Skills

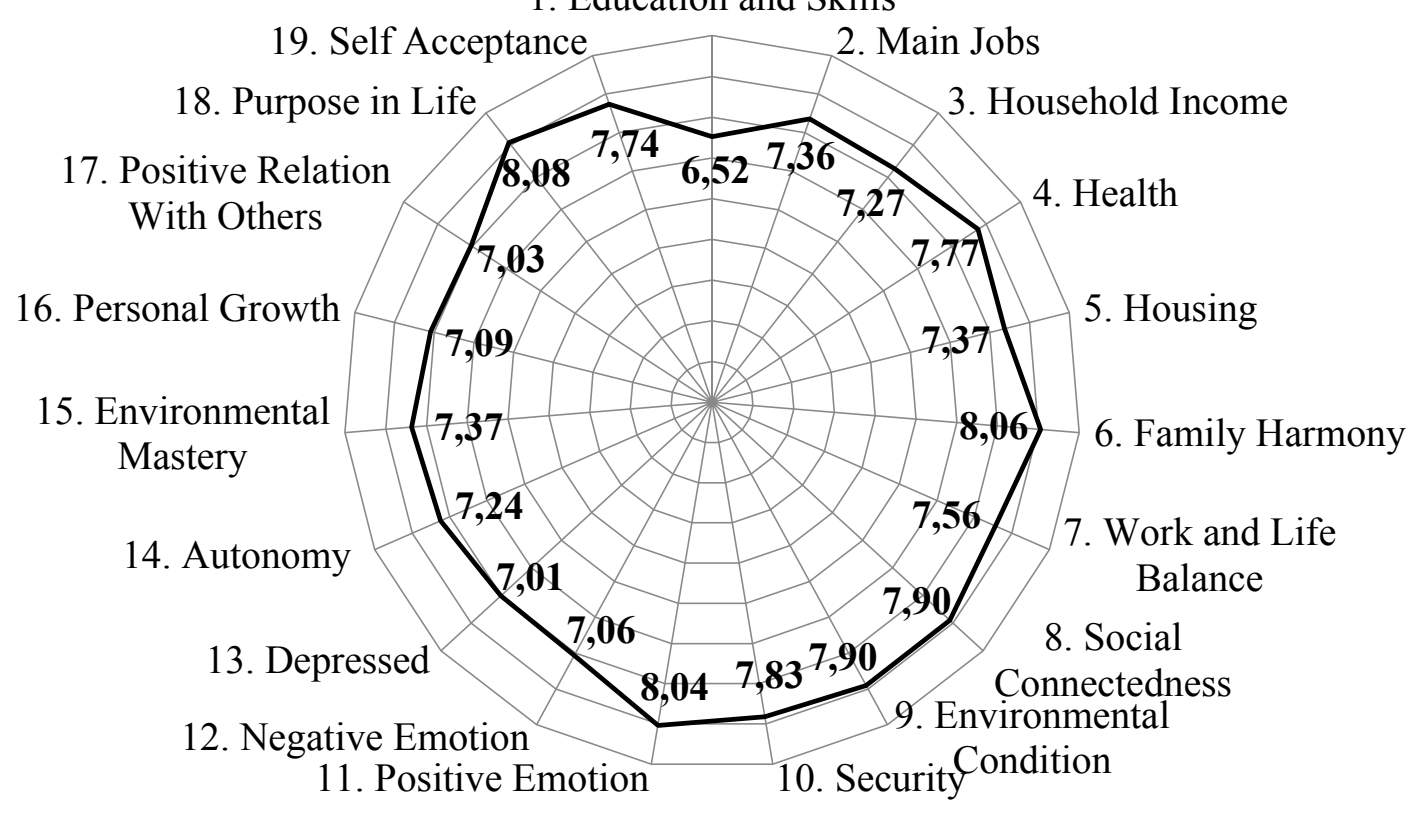

Figure 1. The score of 19 indicators of the Happiness Index 
farming business (Utami and Seruni, 2013). A person's ability to balance time between work and leisure activities independently or with family, relatives, or friends will make a person stay healthy, free from psychic pressures, and productive. The availability of free time contributes greatly to one's happiness (Elfida et al., 2014).

Social Connectedness. Farmers' satisfaction with Social Connectedness was 7.90 (Satisfied). Agricultural activities not only provide material happiness in the form of agricultural production and income, but also non-material happiness in the form of gathering with family, hanging out with neighbors, and interacting with fellow farmers (Permana and Fauzy, 2016). Dairy farmers were members of farmer group organizations. Farmer groups play an important role as institutional means to promote agricultural development through helping farmers solve problems related to agricultural inputs, credit, technical knowledge, and marketing of agricultural products (Msuta and Urassa, 2015).

Environmental Condition. Farmers' satisfaction with the Environmental Condition indicator was 7.90 (Satisfied). Environmental quality was defined as an environmental condition that provides optimal support for survival (Suryani, 2018). The environmental quality of Malang Regency in 2017 , which was quantitatively measured by the Environmental Quality Index (EQI) indicator of 68.5 (Quite Good). Environmental quality has a direct impact on the health and well -being of people and livestock. The topographical condition of mountains and hills makes Malang Regency a cool area that was comfortable for living and raising dairy cows (Heraini et al., 2019).

Security. Farmers' satisfaction with Security was 7.83 (Satisfied). The security condition of the residence affects the creation of a sense of security, comfort in life, and happiness. The safer the greater the comfort so that the greater the happiness of the community (Rahayu, 2016). Activities to maintain the security and order of rural communities were called Sistem Keamanan Lingkungan (SISKAMLING)" (environmental security system), a joint effort of all citizens in improving the security and public order system against threats and disturbances.

\section{Affection Dimension}

Positive Emotion. Farmers' satisfaction with Positive Emotion indicators was 8.04 (Completely Satisfied). Farmers were optimistic about managing dairy farming as their main job. The development of dairy farms was supported by several factors: feed availability, farmer skills, milk demand, farmers' income, market infrastructure, the role of credit institutions, and government policy (Elida, 2016). The strategy for developing the dairy cattle business was to develop the internal capability of farmers, utilizing the natural resources available and introduced new knowledge and technology (Priyanto and Rahmayuni, 2020).

Negative Emotion. Farmers' satisfaction with Negative Emotion indicators was 7.06 (Satisfied). Dairy farmers face a risk of mastitis and low milk prices. Mastitis was one of the main health issues in dairy production and remains a major challenge for the world dairy industry (Jansen et al., 2010). Mastitis causes a decrease in milk production, quality, and price. The price of dairy milk in Malang Regency was between IDR 4,900-5,600/liter, depending on the quality (grade) of milk. Milk quality was determined based on fat content, solids non-fat (SNF), total solid (TS), total plate count (TPC), and antibiotic content. The best quality (Grade A) was IDR 5,300-5,600/liter, medium quality (Grade B) was IDR 5,100-5,300/liter, and low quality (Grade C) was IDR 4,900-5,100/liter.

Depressed. Farmers' satisfaction with Depressed indicators was 7.01 (Satisfied). Smallholder dairy farmers were difficulty scaling up their herd size due to limited farm resources (Khapayi and Celliers, 2016). The local resources became scarce due to the competition in demand among various sectors in the economic activities (Hadiana et al., 2019). Several government programs to help increase the scale of dairy farming business: imported dairy heifer assistance, artificial insemination (AI), small business credit, and cattle insurance. In 2016 the Indonesian govern- 
ment launched the SIWAB (Sapi Induk Wajib Bunting)" Program which means a female cow must be pregnant through artificial insemination and natural mating. The government set a target of 4 million heads of productive female cattle that would be inseminated and reach at least $75 \%$ of pregnancy rates or calving 3 million calves (Rusdiana and Soeharsono, 2017).

\section{Meaning of Life Dimension}

Autonomy. Farmers' satisfaction with the Autonomy indicator was 7.24 (Satisfied). Farmers describe autonomy as a particular lifestyle connected to farming, the equivalent of being one's boss, and the constraints that limit their farming operations (Stock and Forney, 2014). Farmers require entrepreneurship skills in responding to technology development. They have to adopt innovation in their businesses to scale up their welfare (Pambudy, 2018). They have the freedom to access technical information, capital, market, and other information as needed, to increase productivity, business efficiency, and income. Their independence was known from the indicators of awareness and desire to change, the ability to increase the capacity to gain access to technology and capital, the ability to face obstacles, and the ability to cooperate and solidarity with farmers (Rahmawati et al., 2016).

Environmental Mastery. Farmers' satisfaction with Environmental Mastery the indicator was 7.37 (Satisfied). Environmental Mastery was the ability to develop skills that were suitable for their activities or work. Farmers have experience with managing their farms for 10-30 years. They have become proficient in managing their livestock businesses, in terms of technical, economic, social, and political aspects. Assessment of Good Dairy Farming Practices (GDFP) on small-scale dairy farms in Malang Regency was in the "Good" category (Sutawi et al., 2021). The local government provides agricultural advisors whose role was to assist farmers in improving the potential (empowering) they have and developing them (enabling) so that they can be more creative and independent (Rahmawati et al., 2016).
Personal Growth. Farmers' satisfaction with Personal Growth was 7.09 (Satisfied). Farmers were in cooperation with other farmers in dairy cooperatives. Dairy cooperatives provide an organized network of milk marketing along with proper input services like provision of artificial insemination, health care services and quality feed and fodder inputs and also output services like credit facilities, financial support, and animal insurance services with subsidy (Lakshmipriya et al., 2019). Cooperativism may provide opportunities for farmers to access services, information, and resources that will allow them to improve their capacities (Gayatri et al., 2011). Collective action has long been a central mechanism for improving productivity and market access of smallholder producers. The advantages were known to be improved bargaining power, more professional management, linked access to larger volume and markets, and access to higher quality and more reliable inputs and services, including dairy business services. Farmer institutions play a role in determining the productivity of the dairy business by $35 \%$ (Wardani, 2009).

Positive Relation with Others. Farmers' satisfaction with Positive Relation with Other indicators was 7.03 (Satisfied). Positive relationships with others were related to the relationship of a person with someone else. Farmers who have a positive relationship create a sense of caring, empathy, compassion, and mutual trust that makes the respondent's life useful to others. A positive relationship that appeared in a social environment was the major factor and the source of one's happiness (Modiri, 2019). In rural society, a positive relationship among the farmers and the stakeholders as a part of social capital was very important and very helpful for the citizens and the development of the agriculture itself (Wibisono and Darwanto, 2016).

Purpose in Life. Farmers' satisfaction with the indicators of Purpose in Life was 8.08 (Completely Satisfy). Farmers rely on the dairy business as the main job with various motivations: earning daily income, meeting the needs of life, and means of social interaction. Employ- 
ment in a dairy farming farm was a prospective job because domestic milk production was still lacking and milk demand continues to increase. From 2020 to 2022 the milk deficit will reach 115,000 to 139,000 tons (MoA, 2018). The most important factors driving milk demand were population and growth, income levels, the phenomenon of urbanization and market segmentation, and consumer preferences (Agus and Widi, 2018).

Self-Acceptance. Farmers' satisfaction with the indicator of Self-Acceptance was 7.74 (Satisfied). Farmers get the benefits of livestock farming for families, communities, and countries. Dairy farming was a part of agricultural development that aims to provide animal food in the form of highly nutritious fresh milk and milk products, as a source of family income, expand employment opportunities in rural areas. The smallholder livestock business also supports government programs in reducing poverty, providing employment, and a source of income for some rural communities (Kurniawan et al., 2013).

\section{CONCLUSION}

The Happiness Index of small-scale dairy cattle farmers in rural areas of East Java Province was 7.43 and classified as "Happy". Efforts to increase the happiness of farmers can be done by the government and stakeholders by scaling up their herd size, improving the ability of farmers to prevent and treat mastitis, and maintaining the stability of milk prices.

\section{CONFLICT OF INTEREST}

The authors confirm that there was no conflict of interest with any financial, personal, or other relationships with other people or organizations related to this paper.

\section{ACKNOWLEDGEMENTS}

The research for this paper was funded by the Research Grant 2020 of the University of
Muhammadiyah Malang.

\section{REFERENCES}

Agus, A. and T.S.M. Widi. 2018. Current situation and future prospects for beef cattle production in Indonesia - a review. AsianAustralas J. Anim. Sci. 31(7):976-983.

Atmakusuma, J., B.M. Sinaga, N. Kusnadi, and I.K. Kariyasa. 2019. The impact of external and internal factors on the dairy farmer's household economics. Trop. Anim. Sci. J. 42(3):245-252.

BPS (Statistics Indonesia). 2017. Pedoman Pencacahan Survei Pengukuran Tingkat Kebahagiaan 2017. BPS-Statistics Indonesia, Jakarta.

Dodge, R., A.P. Daly, J. Huyton, and L.D. Sanders. 2012. The challenge of defining wellbeing. Int. J. Wellbeing. 2(3):222-235.

Elfida, D., Y.I. Lestari, A. Diamera, R. Angraeni, and S. Islami. 2014. Good relationships with significant people and their contribution to the happiness of Indonesian youth. J. Psikol. 10:66-73.

Elida, S. 2016. Potency and developmental strategy of the dairy cattle business in Pangkalan Kerinci, Pelalawan District. Gontor Agrotech Sci. J. 2(2):53-70.

Firman, A., M. Paturochman, S.L. Budimulyati, M.H. Hadiana, D. Tasripin, O.S. Suwartapradja, and M. Munandar. 2019. Succession decisions in Indonesia family dairy farm business. Livest. Res Rural Dev. 31 (9):1-10.

Foye, C. 2017. The relationship between size of living space and subjective well-being. J. Happiness Stud. 18:427-461.

Gayatri, S., J.T. Dizon, C.M. Rebancos, and N.J.V.B. Querijero. 2011. The dimension of cooperativism and dairy cattle farming in Getasan Village, Semarang Regency, Central Java Province, Indonesia. J. Indonesian Trop. Anim. Agric. 36(2):131-136.

Hadiana, M.H., A.R. Daud, and R.H. Supratman. 2019. Mechanizing the smallholder dairy farm: Its impact on herd size and la- 
bor efficiency. Livest. Res. Rural Dev. 31 (8): $1-9$.

Heraini, D., B.P. Purwanto, and S. Suryahadi. 2019. Comparison of environmental temperature and feed effect on productivity of dairy cattle in the area with different heights. J. Ilm. Peternak. Terpadu. 7(2):234 -240 .

Himani, T., K. Sanjay, R. Rajashree, and T. Kalpna. 2018. Existing housing and breeding management practices adopted by dairy farmers in Tarai region of Uttarakhand, India. Indian J. Anim. Res. 52(3):449-453.

Islam, M.M. 2019. Social determinants of health and related inequalities: Confusion and implications. Frontiers in Public Health. 7 (11):1-4.

Jansen, J., R.J. Renes, and T.J.G.M. Lam. 2010. Evaluation of two communication strategies to improve udder health management. J. Dairy Sci. 93(2):604-612.

Khapayi, M. and P.R. Celliers. 2016. Factors limiting and preventing emerging farmers to progress to commercial agricultural farming in The King William's Town Area of The Eastern Cape Province, South Africa. South Africa J. Agric. Ext. 44(1):25-41.

Kurniawan, M.F.T., D.P. Darmawan, and N.W.S. Astiti. 2013. The development strategy of agribusiness layer poultry in Tabanan Regency. J. Manaj. Agribisnis. 1(2):53-66.

Lakshmipriya, P., R. Raju, S. Sirohi, A.K. Chauhan, P.N. Raju, G. Sankhala, and A. Roy. 2019. Impact of dairy cooperatives on the income of rural households in Andhra Pradesh. Int. J. Agric. Environ. Res. 5(5):585597

Lam, W.W.T., R. Fielding, I. McDowell, J. Johnston, S. Chan, G.M. Leung, and T.H. Lam. 2012. Perspectives on family health, happiness and harmony $(3 \mathrm{H})$ among Hong Kong Chinese people: A qualitative study. Health Educ. Res. 27(5):767-779.

Mandaka, S. and M.P. Hutagaol. 2005. Analysis of profit function, economic efficiency, and possible credit scheme for the development of a scale of people's dairy farming business in Kebon Pedes Village, Bogor City. J. Agro Ekon. 23(2):191-209.

Maoba, S. 2016. Production performance and profitability analysis of small-scale layer projects supported through CASP in Germiston Region, Gauteng Province. South Africa J. Agric. Extension. 44(1):42-49.

MoA (Ministry of Agriculture). 2018. Outlook Susu 2018. Pusat Data dan Informasi Pertanian, Kementerian Pertanian, Jakarta.

Modiri, F. 2019. A Comparison of the shared activities with the spouse between men and women: Similarities and differences. AsiaPacific Soc. Sci. Rev. 19(1):175-188.

Msuta, P.B. and J.K. Urassa. 2015. The contribution of farmers' organizations to smallholder farmers' well-being: A case study of Kasulu District, Tanzania. African J. Agric. Res. 10 (23):2343-2349.

Pambudy, R. 2018. The development of adopting innovation on entrepreneurship status of Madura cattle farmers. Trop. Anim. Sci. J. 41(2):147-156.

Permana, T.S. and M.Q. Fauzy. 2016. Peran pertanian urban pada kesejahteraan petani muslim pada empat kelompok tani di Surabaya ditinjau dari perspektif Islam. J. Ekon. Syariah Teor. Terap. 3(12):945-959.

Priyanto, D and D. Rahmayuni. 2020. Strategy and policy on dairy cattle development in areas outside Java island in supporting domestic fresh milk production. Wartazoa. 30 (3):149-162.

Rahayu, T.P. 2016. The determinants of happiness in Indonesia. J. Ekon. Bisnis. 19:149170.

Rahmawati, I.R., M. Muksin, and R. Rizal. 2016. The role and performance of agriculture extension agent in empowering laying chicken breeders in Jember, East Java Province. J. Penyuluhan. 12(2):183-189.

Rusdiana, S. and Soeharsono. 2017. SIWAB program to improve cattle population and economics value for the business economics. Forum Penelit. Agro Ekon. 35(2):125-137.

Sari, D.P. and H. Puspitawati. 2017. Family conflict and harmony of the farmers' family. J. 
Fam. Sci. 2(1):28-41.

Sharma, M. 2016. Effect of age and educational level of dairy farmers on knowledge and adoption of dairy farming practices in Kapurthala district of Punjab Effect of age and educational level of dairy farmers on knowledge and adoption of dairy farming practices in Kapurth. Int. J. Farm Sci. 6 (4):254-262.

Stock, P.V. and J. Forney. 2014. Farmer autonomy and the farming self. J. Rural Stud. 36:160-171.

Suryani, A.S. 2018. Effect of environmental quality on fulfillment of basic needs in Banten Province. Aspirasi: J. Masal. Sos. 9(1):3462.

Sutawi, I. Prihartini, A. Malik, and S.N.W. Mulatmi. 2021. Assessment of good dairy farming practices on small-scale dairy farms in Malang Regency of East Java, Indonesia. Livest. Res. Rural Dev. 33(1):1-7.

Utami, H.D. and A.P. Seruni. 2013. Determinants of household labor allocation to small-scale dairy farming activities. Livest. Res. Rural Dev. 25(10):1-8.

Utami, H.D. and A.P. Seruni. 2014. Financial performance of small-scale dairy farming in East Java Indonesia. Livest. Res. Rural Dev. 26(11):1-7.

Wardani. 2009. Hubungan antara bentuk kelembagaan dan rantai pasar dengan produktivitas usaha susu segar. J. Penyul. Pertan. 4 (1):32-42.

Wibisono, G.M.A. and Darwanto. 2016. Strategy of strengthening social capital of farmer group in agricultural development. Jejak: J. Ekon. Kebijak. 9(1):62-81.

Yakubu, A. and R. Aidoo. 2015. The determinants of subjective well-being among subsistence farmers in the Northern Region of Ghana. J. Agric. Econ. Dev. 4(2):14-20.

Zuroida, R. and R. Azizah. 2018. Cages sanitation and health complaints among dairy farmers in Murukan Village, Jombang. J. Kesehat. Lingkung. 10(4):434-440. 